The Burrows Company of Cleveland have issued a volume, by H. B. Fuller, on The Purchase of Florida, its History and Diplomacy.

A volume entitled Paix japonaise, by Louis Aubert, has recently appeared (Librairie Armand Colin). This is a very interesting sketch of recent events in the Orient, including an account of the Portsmouth peace negotiations. It is not at all friendly to the United States, but it may serve to offset some of the extravagant claims which have been made in this country as to the success of John Hay's open-door policy.

A seventh volume has been added to The International Library of works devoted to the movement for peace and arbitration. The title of this new volume is The Moral Damage of War, and is by Rev. Walter Walsh, of Dundee. The Library is published for the International Union by Ginn \& Co.

\title{
Recent Important Judicial Decisions
}

\section{B. F. SHAWBAUGH}

Federal Tax on State Liquor Dispensers. The State liquor dispensers of South Carolina are not a necessary State agency and hence are liable to the special tax imposed by the internal revenue laws.

South Carolina v. United States, 26 Sup. Ct. 110.

DECReE of Divorce. In a cuse where a husband deserted his wife in New York, established a domicile in Connecticut and there secured a divorce on notice by publication only, the wife not appearing in the suit, it was held that New York was not bound by the full faith and credit clause of the Federal Constitution to recognize this decision as affecting the status of the wife.

This decision is rather starting, in that, it is contrary to the holding of a majority of the State courts and the distinction seems very slight between this $r$ ise and Atherton v. Atherton, 181 U. S. 155, in which the United States Supreme Court itself reached an opposite conclusion.

Haddock v. Haddock, 26 Sup. Ct. 525.

Discrimination Between Races. ("Jim Crow Cars"). An act requiring street car companies to provide separate compart- 
ments in their cars for the caucasian and ethiopian races and requiring the persons of each race to occupy their respective compartments, and providing further "that the provisions of this act shall not apply to colored nurses having the care of white children or sick white persons" is unconsititutional.

State v. Patterson (Fla.) 39, So. 398.

A similar statute in Tennessee is held constitutional as a proper police regulation not abridging the privileges and immunities of the citizen or depriving him of the equal protection of the laws.

Morrison v. State (Tenn.), 95 S. W. 494.

INHERITANCE TAX. It is held that a graduated tax on inheritances is not in conflict with the constitutional requirement that taxation shall be uniform and levied upon such property as the legislature shall prescribe, or with the provision guaranteeing due process of law.

Nunnemacher v. State (Wis.), 108 N. W. 627.

Marriage of Epileptics. A statute prohibiting marriage by an epileptic is not in contravention of a constitutional provision for equality in the rights to liberty and the pursuit of happiness.

Gould v. Gould (Conn.) 61 At. 604.

Due Process of Law. A Pennsylvania statute providing for the administration of the property of persons absent and unheard of for seven years and presumed to be dead was held to be a valid enactment not repugnant to the fourteenth amendment as depriving the absentee of his property without due process of law.

Cunnivs, now Smith v. Reading School District, 198, U. S. 458.

A similar statute in Maryland was held unconstitutional, this case being distinguished from the above by the fact that the Pennsylvania statute made provision for the protection of the rights of the absentee should he afterward prove to be alive, which provision was not made in the Maryland statute.

Savings Bank of Baltimore v. Weeks, 64 At. 295.

Privileges or Immunities. An Iowa statute providing for preference over others equally competent of honorably discharged soldiers and sailors of the Civil War, residents of the State, in appointment to public service violates neither the fourteenth amendment to the Federal Constitution which declares that no State shall make or enforce any law abridging the privileges or immunities of the citizens 
of the United States, nor a clause of the State Constitution forbidding the granting to any class of privileges not open to all.

Shaw v. City Council of Marshalltown (Ia.), 104 N. W. 1121.

Control of Governor by Mandamus. A State statute directed the governor to approve with his own signature treasury warrants for the salaries of certain military officers. He refused to do so and the mandamus proceeding was resisted on the ground that the governor of a State is not amendable to the compulsory process of the courts.

Held, that the act required being purely ministerial, mandamus would lie to compel performance by the governor.

Cocran et al. v. Beckham, Governor et al., 89 S. W. 262.

Appropriation for Private Purpose-Sugar Bounty. A Nebraska statute offering a bounty for the manufacture of sugar and chicory was held unconstitutional because of lack of power on the part of the legislature to appropriate money for such purpose.

Oxnard Beet Sugar Co. v. State, 105 N. W. 716.

Patented Articles. A statute of Arkansas provided that every negotiable instrument taken in payment for any patented machine, implement, substance, or instrument shall be executed on a printed form showing upon its face that it was so taken, and that all negotiable instruments not so showing on their face should be absolutely void. Held, that such statute was unconstitutional and void as creating a discrimination between articles of property of the same class based solely on the fact that those discriminated against were protected by a United States patent.

Ozan Lumber Co. v. National Bank, Fed. 344.

The authorities are in hopeless conflict as to whether a State may impose restrictions on the sale of patent rights. As a general proposition, however, the State may impose reasonable police regulations upon the sale of certain classes of property even though patented articles may be included in the class. The above decision does not necessarily depart from this rule. It merely decides that the basis of discrimination cannot be the fact that the articles discriminated against are patented.

Authority of a Governor to Sue. Under a general constitutional clause requiring the governor to see that the laws are duly enforced it was held that the governor does not have authority to sue in the name of the State.

Henry v. State, 39 So. 856. 
Personal Liberty. The general provisions of the Nebraska "Dipsomaniac law" were held constitutional but that part of the law which sought to impose conditions on the release of one who had been cured was unconstitutional as a violation of the right to personal liberty.

Ex parte Schwarting, 108 N. W. 125.

The United States district court for western Tennessee in December, declared unconstitutional the employers' liability law of 1906, on the ground that the liability of a common carrier to its employees for injuries, is not a part of interstate commerce. The case has been appealed.

Poulce Powkr. A statute prohibiting any female from being employed, permitted, or suffered to work in any factory before 6 o'clock in the morning or after 9 o'clock in the evening of any day is not a valid exercise of police power in the interest of the health of female employees and the public welfare,.

People v. Williams, 100 N. Y. Supp. 327. 